Review article

\title{
Treatment of Patients with Risk Factors: Compliance and Adherence
}

\author{
Rok Accetto ${ }^{1,2}$, Simona Korenčan ${ }^{1,2}$, Sonja Radenković3 ${ }^{3}$ Jelena Milenković ${ }^{3}$ \\ ${ }^{1}$ University Medical Center Ljubljana, Division of Internal Medicine, Clinical Department for Hypertension, Ljubljana, \\ Slovenia \\ ${ }^{2}$ Faculty of Medicine, Department of Internal Medicine, Ljubljana, Slovenia medicine \\ ${ }^{3}$ University of Niš, Faculty of Medicine, Institute for Pathophysiology, Niš, Serbia
}

\section{SUMMARY}

Hypertension and dyslipidemias represent important risk factors for the occurrence of cardiovascular diseases which have a high mortality rate. Although we know how to treat both, the success rate remains low. More than half of patients need at least two antihypertensive agents to achieve target blood pressure. Also, dyslipidemia frequently coexists and thus the burden of life-long pill taking is high and the adherence is low. We suggest treating both conditions simultaneously in a fixed combination. This would increase patients' adherence and compliance to therapy and therefore provide a more successful management of both conditions.

Key words: hypertension, dyslipidemias, blood pressure, fixed combination, adherence, compliance, risk factors 


\section{INTRODUCTION}

Life expectancy in Slovenia is 83 years for women and 77 years for men (1). Data from 2012 published by Eurostat show that cardiovascular diseases are the leading cause of death in Europe (393.6 per 100,000 population), as well as in Slovenia (462 per 100,000 population), and most often it comes to ischemic heart disease (in Europe 136.8 per 100,000 population in Slovenia 118.5 per 100,000 population). Cardiovascular diseases are followed by cancer in the second place (2). Chronic cardiovascular diseases are mostly associated with risk factors. Data by WHO from 2004 displaying the mortality rate of people in relation to 19 risk factors showed that the leading risk factor is high blood pressure, followed by tobacco use, elevated blood glucose, physical inactivity, overweight and obesity, elevated cholesterol, alcohol consumption, etc. (3). Some can be managed by individuals themselves, others require medical help (4). Age, gender, family burden, ethnicity, previous CVI and TIA represent unmanageable risk factors (5). During the first decade of the $21^{\text {st }}$ century, the share of cardiovascular diseases in the total mortality rate was $56 \%$ in Serbia (780 per 100,000 population), which puts Serbia into the group of ten most threatened countries in the world.

The southeast part of Serbia is regionally most threatened, and mortality rate from cardiovascular diseases is almost double compared to the country as a whole (1,415.5 per 100,000 population). In the region of Niš, the rate is also significantly high (higher than 1,000 per 100,000 population). It is important that every second resident in Serbia has increased blood pressure (47\%). Out of this number, half of the population is not aware of having high blood pressure, and more than $50 \%$ of those who know to have hypertension do not treat it. The basic risk factors for hypertension in Niš region are genetic predisposition, increased consumption of alcohol, sweetened carbonated and non-carbonated beverages, improper diet, increased blood lipids, physical inactivity and obesity. Years of age are independent predictor of arterial hypertension development (6).

\section{Cardiovascular risk}

Cardiovascular risk is estimated by risk charts. For a long period of time we have used the so-called Framingham risk charts, which are based on epidemiological data of the North American population. Today, however, we recommend the use of charts adapted to the European population, the so-called SCORE charts, which are based on the results of 12 cohort studies (including more than 25,000 patients) conducted in Europe (7).

The management of individual risk factors and its influence on cardiovascular morbidity and mortality have been confirmed by numerous clinical studies. We will focus on hypertension and dyslipidemia, which are undoubtedly the most important factors which can be successfully treated.

\subsection{Management of hypertension}

In 1994, a meta-analysis of 16 studies was published (HDFP, MRC, Shep and 13 others), which confirmed that the morbidity and mortality due to stroke and chronic heart diseases and their risk was significantly lower in the groups treated with antihypertensive therapy, in comparison with the control group. Since then, the effectiveness and necessity of antihypertensive therapy is indisputable (8). An average reduction of blood pressure by $2 \mathrm{mmHg}$ reduces the risk of mortality from ischemic cardiac disease by $7 \%$ and the risk of mortality from stroke by $10 \%$ (9). Many clinical studies have confirmed that the main benefit of hypertension management is due to the decrease in blood pressure per se and not due to a specific antihypertensive drug (10).

Thus, the guidelines advise that diuretics (hydrochlorothiazide, chlorthalidone and indapamide), beta-blockers, calcium antagonists, converting enzyme inhibitors and angiotensin II receptor blockers are suitable for initial and follow-up treatment as monotherapy as well as in combination. Regardless of the antihypertensive drug used, we can effectively lower blood pressure with monotherapy by only a limited number of patients (11). The majority of hypertensive patients requires a combination of at least two drugs to successfully manage blood pressure. More than half of them are taking two or more antihypertensive drugs (12). To achieve the target blood pressure $(140 / 90 \mathrm{mmHg}$ and 130/80 $\mathrm{mmHg}$ in diabetics), general practitioners need to prescribe in $40.9 \%$ a combination of two antihypertensives, in $22.3 \%$ a combination of three or more antihypertensive agents, and only about one third $(36.8 \%)$ of patients were treated with monotherapy (13).

Despite a high prevalence of hypertension and its colossal impact on morbidity and mortality, and broad spectrum of antihypertensive medications, only $31.8 \%$ of treated patients are controlled (blood pressure below 140/90) in Slovenia. When compared to other countries, 
we belong to the medium developed Western European countries $(10,14)$. In Niš region, only $25 \%$ of arterial hypertension patients attend medical controls, being treated regularly. According to the evidence-based results of the possibility of successful hypertension management, we believe that more attention should be paid to this problem. According to the result of our study of the Serbian population, $51.6 \%$ of patients with arterial hypertension were females, $61.4 \%$ patients were older than 65 years of age, while $85.3 \%$ patients were older than 75 (10).

\subsection{Management of dyslipidemias}

Dyslipidemias include a wide range of disorders, most of which have a major influence on the development of cardiovascular diseases, thus prevention of dyslipidemias is essential for the management of cardiovascular risk. Fat metabolism may be disturbed on several levels, leading to change in function and amount of plasma lipoproteins. We focus mainly on measuring the total cholesterol and LDL cholesterol values, since we can influence them with a healthy lifestyle as well as with drugs (12).

Meta-analysis of 61 prospective studies with 900,000 adult participants showed that mortality due to cardiovascular disease increases linearly with the amount of total cholesterol in blood. Lowering serum cholesterol levels can significantly lower mortality due to cardiovascular disease as lowering cholesterol for 0.1 $\mathrm{mmol} / \mathrm{l}$ leads to a reduction in mortality by $4 \%$ (15).

Prevention and treatment of dyslipidemia should always be considered within a broader framework of CVD prevention, which is addressed more precisely in guidelines of the Joint European Societies (7).

In addition to standard treatment we should aim to prevent further increase in cardiovascular risk, promote awareness and primary prevention of cardiovascular disease and its risk factors. According to the latest European guidelines, the target LDL cholesterol in people with very high risk is $<1.8 \mathrm{mmol}$ /L; however, if this is not attainable, we should seek to reduce LDL cholesterol by $>50 \%$. The targets in people with high and moderate risk are $<2.5 \mathrm{mmol} / \mathrm{L}$ and $<3$ $\mathrm{mmol} / \mathrm{L} \quad(14,16)$. Euroaspire IV shows that implementation of guidelines concerning treatment of dyslipidemia is far from optimal (17).

A study, which included data from three different sources (National Health and Nutrition
Examination Survey 2007-2008, Administrative Claims Data 2003 - Sept 2010 and Electronic Medical Records 2003 - September 2010) showed that less than a third of all patients with chronic heart disease achieves cholesterol $<70 \mathrm{mg} / \mathrm{dL}$; moreover, in high-risk patients, this proportion is significantly lower and does not reach more than $14.3 \%$ in any of the three sources (18).

Recent studies have shown that treatment with lipid-lowering agents in patients with high blood pressure and other risk factors is beneficial, irrespective of baseline lipid level (18).

An important clinical trial called ASCOT (Anglo-Scandinavian Cardiac Outcomes Trial) compared the standard antihypertensive therapy of beta-blocker and a thiazide diuretic and also the antihypertensive therapy of calcium channel blockers and ACE inhibitors in combination with a statin. Irrespective of the initial cholesterol concentrations, with addition of atorvastatin to antihypertensive therapy, the risk of coronary events, stroke and death due to cardiovascular causes was further reduced (19). The findings of this research were confirmed by other studies, which have shown that the risk of cardiovascular events, coronary events, myocardial infarction, chronic heart disease, total mortality, cardiovascular mortality, stroke and heart failure is significantly reduced when treated with atorvastatin compared to treatment with placebo (20).

Although the treatment of hypertension and dyslipidemia is undoubtedly successful in reducing the cardiovascular risk, the current situation in the population is unsatisfactory. In a population of 154,235 treated patients, more than $90 \%$ of the patients did not reach the target cholesterol and blood pressure value (18).

As we mentioned, a simultaneous control of hypertension and dyslipidemia is important in reducing morbidity and mortality due to cardiovascular diseases. Why does a relatively large percentage of patients not reach the target values? An important reason lies in a lower adherence and compliance to therapy.

\section{Adherence to therapy}

An approach to patients with risk factors for cardiovascular disease is composed of three steps: awareness, treatment, and control. Awareness represents a problem, since the risk factors are usually asymptomatic in early stages; therefore, the patient sees 
no true value of the treatment. This often leads to poor patient adherence to treatment, which is one of the key problems. Adherence is defined as the degree of the patient's behavior related to the use of medication, as well as following advice regarding diet, maintenance of a healthy lifestyle and sticking to arrangements and advice of the healthcare team. It may be low due to the psychological burden of realizing they are at risk for cardiovascular disease, the burden of lifelong therapy, and the side effects of drugs.

When drug therapy is tailored for the individual patient, its importance is presented to them in an understandable way, the adherence and compliance rise, as does the successful control of hypertension.

In addition to the potential benefits of synergistic effects of two antihypertensive drugs from different groups, there is a greater adherence to treatment, if it is a fixed combination already at the beginning of the treatment. It is true, however, that potential side effects can be expected.

A single pill usage - a fixed combination of two active ingredients, could be a way to achieve better blood pressure control due to better adherence to treatment (21). Cohort studies-based analyses indicate that the use of fixed antihypertensive drugs combinations is associated with a significant improvement of drug adherence. In addition, the use of the fixed combination is associated with a positive trend towards a reduction in blood pressure as well as reported adverse events.

In one study, more than a $29 \%$ increase in drug adherence was observed, when patients were treated with combination of two antihypertensive drugs, which is in concordance with meta-analysis of drug adherence when using fixed combinations of multiple medications for other health conditions such as diabetes, etc. (22). Many other studies have confirmed that compliance significantly rises with combination treatment (23). In five different studies, persistence of patients using antihypertensive medications for at least 12 months was observed. It resulted in $20.9 \%$ persistence in free-drug combination compared with $59.3 \%$ in the combination treatment (24). The potential causes of non-adherence are the complexity of treatment, side effects of treatment, lack of understanding of the importance of treatment and the cost of drugs that often represent a burden to the patient (25).

A retrospective study about patients' engagement in the treatment of hypertension and dyslipidemia showed that it is improves when taking medications for both diseases simultaneously and with a reduction in the number of added drugs for various diseases (26).

\section{CONCLUSION}

Combination treatment of hypertension in Slovenia is not new as already in 1977 dr. Jurij Dobovišek stated that the best results in the treatment of arterial hypertension are achieved by the so-called targeted polypragmasia, a combination of several antihypertensive drugs with different mechanisms of actions. Thereby, we achieve a greater overall impact and reduce the dosage of each compounds and thus observe less side-effects (27).

Introduction of combination treatment of arterial hypertension in Serbia also began in 70s of the last century. It was shown that this approach is more effective for the treatment of disease especially in the population of elderly, which already have low adherence due to a larger number of medications in use.

A fixed combination of two or more agents for the management of multiple risk factors contributes to achieving the target values alongside better adherence and persistence to therapy. There are many evidences showing less side-effects. 


\section{References}

1. World Health Organisation. World health statistics 2013; 2013. Available from: http://www.who.int/gho/publications/world_hea 1th_statistics/EN_WHS2013_Full.pdf.

2. Eurostat Press Office. Europe in figures Eurostat yearbook 2012 A gateway to European statistics; 2012 May 11. Available from: http://europa.eu/rapid/press-release_STAT-1270_en.htm?locale=en.

3. World Health Organization. Global health risks: mortality and burden of disease attributable to selected major risks. WHO Library Cataloguingin-Publication Data; 2009.

4. Lindsay P, Bayley M, Hellings C et al. Canadian Stroke Strategy Best Practices and Standards Writing Group on behalf of the Canadian Stroke Strategy, a joint initiative of the Canadian Stroke Network and the Heart and Stroke Foundation of Canada. Canadian best practice recommendations for stroke care (updated 2008). CMAJ 2008; 179:E1-E93. https://doi.org/10.1503/cmaj.081148.R2

5. Yusuf S, Hawken S, Ounpuu S et al. Effect of potentially modifiable risk factors associated with myocardial infarction in 52 countries (the INTERHEART study): Case-control study. Lancet 364:937-52. https://doi.org/10.1016/S0140-6736(04)17018-9

6. Radenković S. Rezistentna arterijska hipertenzija : etiopatogenetski, dijagnostički i terapijski karakteri. 1. izd. Medicinski fakultet, Punta, Niš, 2013: 219.
7. Reiner Z, Catapano A, De Backer G et al. ESC/EAS Guidelines for the management of dyslipidaemias. Eur Heart J 2011; 32: 1769-818. https://doi.org/10.1093/eurhearti/ehr158

8. Collins R, MacMahon S. Blood pressure, antihypertensive drug treatment and the risks of stroke and of coronary heart disease. Brit Med Bull 1994; 50: 272-98.

9. Lewington S, Clarke R, Qizilbash N et al. Agespecific relevance of usual blood pressure to vascular mortality: A meta-analysis of individual data for one million adults in 61 prospective studies. Lancet 2002;360: 1903-13. https://doi.org/10.1016/S0140-6736(02)11911-8

10. Fretheim A, Odgaard-Jensen J, Brors $\mathrm{O}$ et al. Comparative effectiveness of antihypertensive medication for primary prevention of cardiovascular disease: Systematic review and multiple treatments meta-analysis. BMC Medicine 2012; 10:33.

https://doi.org/10.1186/1741-7015-10-33

11. Accetto R, Dobovišek J, Dolenc P et al. Slovenske smernice za obravnavo arterijske hipertenzije (2003). Zdrav Vestn 2004; 73: 507-17.

12. Petek-Šter M, Švab I. Nadzor krvnega tlaka pri bolnikih z arterijsko hipertenzijo $\mathrm{v}$ Sloveniji.(Blood pressure control in patients with arterial hypertension in Slovenia). Zdrav Vestn 2007; 76: 397-403.

13. Giannattasio C, Cairo M, Cesana F et al. Blood pressure control in Italian Essential Hypertensives Treated by General practitioners. Am J 
Hypertens 2012; 25: 1182-7.

https://doi.org/10.1038/ajh.2012.108

14. Accetto R, Salobir B. Epidemiološka raziskava hipertenzije v Sloveniji delno poročilo. V: Dolenc P, ur. XVIII. Strokovni sestanek Sekcije za arterijsko hipertenzijo. Zbornik. Portorož, 26.-27. november 2009. Sekcija za arterijsko hipertenzijo, Ljubljana,2009: 9-18.

15. Studies P, Lewington S, Whitlock G et al. Blood cholesterol and vascular mortality by age, sex, and blood pressure: A meta-analysis of individual data from 61 prospective studies with 55, 000 vascular deaths. Lancet 2007; 370:18291839.

https://doi.org/10.1016/S0140-6736(07)61778-4

16. Fras Z, Jug B. Pregled in poudarki ESC/EAS smernic za obravnavo dislipidemij 2011. Slovenski forum za preventivo bolezni srca in žilja 2012. Zbornik, Ljubljana, 2012.

17. Kotsev K, Woo D, De Bacque D et al. EUROASPIRE IV: A European Society of Cardiology survey on the lifestyle, risk factor and therapeutic management of coronary patients from 24 European countries. Eur J Prev Card2016;23:636-48.

https://doi.org/10.1177/2047487315569401

18. Jones PH, Nair R, Thakker KM. Prevalence of Dyslipidemia and Lipid Goal Attainment in Statin-Treated Subjects From 3 Data Sources: A Retrospective Analysis. J Am Heart Ass 2012;1. https://doi.org/10.1161/jaha.112.001800

19. 19. Brookes L. ASCOT: Anglo Scandinavian Cardiac Outcomes Trial. Medscape. Oct 04, 2005. Available from:

http://www.medscape.com/viewarticle/513974

20. Heart Protection Study Collaborative Group. MRC/BHF Heart Protection Study of cholesterol lowering with simvastatin in 20536 high-risk individuals: a randomised placebo-controlled trial. Lancet 2002; 360:7-22.

https://doi.org/10.1016/S0140-6736(02)09327-3

21. Gupta AK, Arshad S, Poulter NR. Compliance, Safety, and Effectiveness of Fixed-Dose Combinations of Antihypertensive Agents. A Meta-Analysis. Hypertension 2010; 55:399-407. https://doi.org/10.1161/HYPERTENSIONAHA.109.139 $\underline{816}$

22. Bangalore S, Kamalakkannan G, Parkar S et al. Fixed-dose combinations improve medication compliance: a meta-analysis. Am J Med 2007; 120:713-9.

https://doi.org/10.1016/j.amjmed.2006.08.033

23. Burnier M. Medication adherence and persistence as the cornerstone of effective antihypertensive therapy. Am J Hypertens 2006; 19:1190-6.

https://doi.org/10.1016/j.amjhyper.2006.04.006

24. Sherrill B, Halpern M, Khan S et al. Single-Pill vs Free-Equivalent Combination Therapies for Hypertension: A Meta-Analysis of Health Care Costs and Adherence. J Clin Hypertens 2011; 13: 898-909.

https://doi.org/10.1111/j.1751-7176.2011.00550.x

25. Benner JS, Glynn RJ, Mogun H et al. Long-term persistence in use of statin therapy in elderly patients. JAMA 2002; 288:455-61.

https://doi.org/10.1001/jama.288.4.455

26. Chapman R, Benner J, Petrilla AA et al. Predictors of adherence with Antihypertensive and lipid-lowering therapy. Value in Health 2004; 7:319.

https://doi.org/10.1016/S1098-3015(10)62371-6

27. Dobovišek J. Zdravljenje arterijske hipertenzije. Obzornik zdravstvene nege 1977;11: 21-8. 


\title{
Lečenje bolesnika sa faktorima rizika: komplijansa $i$ adherenca
}

\author{
Rok Accetto ${ }^{1,2}$, Simona Korenčan ${ }^{1,2}$, Sonja Radenković3 ${ }^{3}$ Jelena Milenković ${ }^{3}$ \\ ${ }^{1}$ Univerzitetski medicinski centar Ljubljana, Odeljenje za internu medicinu, Klinički departman za lečenje \\ hipertenzije, Ljubljana, Slovenija \\ ${ }^{2}$ Medicinski fakultet, Departman za internu medicinu, Ljubljana, Slovenija \\ ${ }^{3}$ Univerzitet u Nišu, Medicinski fakultet, Institut za patofiziologiju, Niš, Srbija
}

\section{SAŽETAK}

Hipertenzija i dislipidemije predstavljaju važne faktore rizika za nastanak kardiovaskularnih bolesti koje beleže visoku stopu mortaliteta. Iako znamo kako da lečimo obe vrste oboljenja, stopa uspešnosti lečenja još uvek ostaje niska. Kod više od polovine bolesnika neophodno je prepisati najmanje dva leka protiv povišenog krvnog pritiska kako bi se postigle njegove ciljane vrednosti. Takođe, veoma često se istovremeno javlja i dislipidemija, tako da su bolesnici opterećeni zbog doživotnog uzimanja lekova $i$ adherenca je niska. Predlažemo da se oba stanja leče istovremeno, tačno određenom kombinacijom lekova. Ovakav režim bi povećao adherencu i komplijansu i samim tim omogućio uspešnije lečenje oba stanja.

Ključne reči: hipertenzija, dislipidemije, krvni pritisak, fiksni režim, adherenca, komplijansa, faktori rizika 